\title{
Newer agents in antiplatelet therapy: a review
}

\author{
This article was published in the following Dove Press journal: \\ Journal of Blood Medicine \\ 22 June 2012 \\ Number of times this article has been viewed
}

\section{Jennifer Yeung Michael Holinstat \\ Cardeza Foundation for Hematologic Research, Department of Medicine, Thomas Jefferson University, Philadelphia, PA, USA}

\begin{abstract}
Antiplatelet therapy remains the mainstay in preventing aberrant platelet activation in pathophysiological conditions such as myocardial infarction, ischemia, and stroke. Although there has been significant advancement in antiplatelet therapeutic approaches, aspirin still remains the gold standard treatment in the clinical setting. Limitations in safety, efficacy, and tolerability have precluded many of the antiplatelet inhibitors from use in patients. Unforeseen incidences of increased bleeding risk and recurrent arterial thrombosis observed in patients have hampered the development of superior next generation antiplatelet therapies. The pharmacokinetic and pharmacodynamic profiles have also limited the effectiveness of a number of antiplatelet inhibitors currently in use due to variability in metabolism, time to onset, and reversibility. A focused effort in the development of newer antiplatelet therapies to address some of these shortcomings has resulted in a significant number of potential antiplatelet drugs which target enzymes (phosphodiesterase, cyclooxygenase), receptors (purinergic, prostaglandins, protease-activated receptors, thromboxane), and glycoproteins ( $\alpha \mathrm{IIb} \beta 3, \mathrm{GPVI}, \mathrm{vWF}, \mathrm{GPIb})$ in the platelet. The validation and search for newer antiplatelet therapeutic approaches proven to be superior to aspirin is still ongoing and should yield a better pharmacodynamic profile with fewer untoward side-effects to what is currently in use today.
\end{abstract}

Keywords: platelet aggregation inhibitors, blood platelets, purinergic P2Y receptor antagonists, receptor, PAR-1, platelet glycoprotein GPIIb-IIIa, thrombosis

\section{Introduction}

Antiplatelet drugs are the cornerstone in treatment of cardiovascular diseases. Despite the significant decrease in morbidity and mortality due to the currently approved antiplatelet drugs, recurrent ischemia, myocardial infarction (MI), and unwanted bleeding still occur. The majority of drugs in development have focused on targeting either surface receptors or enzymes in the platelet in order to protect against unwanted clot formation following initial platelet activation. The first target for antiplatelet therapy was cyclooxygenase- 1 by aspirin. While newer approaches for containing platelet activity have been developed, the pharmacodynamics and pharmacoeconomics suggest that aspirin will continue to be a mainstay for platelet therapy in the years to come. Currently, a combination regimen of aspirin and clopidogrel is the standard of care for prevention of platelet activation, thrombosis, and stroke. Unfortunately many of the current antiplatelet drugs face limitations in their utility due to genetic differences in the ability to metabolize pro-drugs, such as is the case with clopidogrel, acquired allergic responses such as is seen with heparin and aspirin, and resistance as has been reported with aspirin (see Table 1). Additional limitations observed in the application
Correspondence: Michael Holinstat 1015 Walnut Street, 320B Curtis Building, Philadelphia, PA, USA

Tel + I 2I5955 6I2I

Fax +I 2159559170

Email michael.holinstat@jefferson.edu 
Table I Approved antiplatelet drugs

\begin{tabular}{|c|c|c|c|c|c|}
\hline Drug & Target & Half-life & Side effects & Bioavailability & Use \\
\hline $\begin{array}{l}\text { Ticlopidine } \\
\text { (Ticlid) }\end{array}$ & P2YI2 receptor & 12 hours & $\begin{array}{l}\text { Bleeding, rash, neutropenia, thrombotic } \\
\text { thrombocytopenic purpura (rare), nausea, } \\
\text { vomiting, heartburn, indigestion }\end{array}$ & Oral & $\begin{array}{l}\text { Transient ischemic } \\
\text { attacks, patients } \\
\text { undergoing } \mathrm{PCl}\end{array}$ \\
\hline $\begin{array}{l}\text { Clopidogrel } \\
\text { (Plavix) }\end{array}$ & $\mathrm{P} 2 \mathrm{Y} 12$ receptor & $6-8$ hours & $\begin{array}{l}\text { Bleeding, rash, neutropenia, thrombotic } \\
\text { thrombocytopenic purpura (rare) }\end{array}$ & Oral & $\begin{array}{l}\text { NSTEMI, STEMI, PCI, } \\
\text { recent stroke, or } \\
\text { established PAD }\end{array}$ \\
\hline $\begin{array}{l}\text { Prasugrel } \\
\text { (Effient) }\end{array}$ & $\mathrm{P} 2 \mathrm{Y} \mid 2$ receptor & 8 hours & Bleeding & Oral & $\begin{array}{l}\text { Patients with } \mathrm{ACS} \\
\text { undergoing } \mathrm{PCl}\end{array}$ \\
\hline $\begin{array}{l}\text { Ticagrelor } \\
\text { (Brilinta) }\end{array}$ & P2Y 12 receptor & $6-12$ hours & Dyspnea & Oral & STEMI, ACS \\
\hline $\begin{array}{l}\text { Abciximab } \\
\text { (ReoPro) }\end{array}$ & GPIlb-IIla & $<10-30$ minutes & $\begin{array}{l}\text { Bleeding, thrombocytopenia, EDTA-induced } \\
\text { psuedothrombocytopenia }\end{array}$ & IV & $\mathrm{PCl}$ \\
\hline $\begin{array}{l}\text { Eptifibatide } \\
\text { (Integrilin) }\end{array}$ & GPIlb-IIla & $\sim 2.5$ hours & $\begin{array}{l}\text { Bleeding, thrombocytopenia, EDTA-induced } \\
\text { psuedothrombocytopenia }\end{array}$ & IV & $\begin{array}{l}\text { NSTEMI, PCl, unstable } \\
\text { angina }\end{array}$ \\
\hline $\begin{array}{l}\text { Tirofiban } \\
\text { (Aggrastat) }\end{array}$ & GPIlb-IIla & 2 hours & $\begin{array}{l}\text { Bleeding, thrombocytopenia, EDTA-induced } \\
\text { psuedothrombocytopenia }\end{array}$ & IV & $\begin{array}{l}\text { NSTEMI, PCl, unstable } \\
\text { angina }\end{array}$ \\
\hline $\begin{array}{l}\text { Cilostazol } \\
\text { (Pletal) }\end{array}$ & PDE3 & $11-13$ hours & $\begin{array}{l}\text { Headache, dizziness, hypotension, flushing, } \\
\text { nausea, vomiting, diarrhea, abdominal pain }\end{array}$ & Oral & $\begin{array}{l}\text { Intermittent } \\
\text { claudication, PAD, PCI }\end{array}$ \\
\hline $\begin{array}{l}\text { Dipyridamole } \\
\text { (Aggrenox) }\end{array}$ & $\begin{array}{l}\text { PDE3 and inhibition } \\
\text { of adenosine uptake }\end{array}$ & 10 hours & $\begin{array}{l}\text { Bleeding, headache, diarrhea, palpitations, } \\
\text { dizziness, rash, pancytopenia }\end{array}$ & Oral & $\begin{array}{l}\text { Transient ischemic } \\
\text { attacks }\end{array}$ \\
\hline
\end{tabular}

Abbreviations: ACS, acute coronary syndromes; EDTA, ethylenediaminetetraacetic acid; GP, glycoprotein; IV, intravenous; NSTEMI, non-ST elevation myocardial infarction; PAD, peripheral arterial disease; PCI, percutaneous coronary intervention; PDE, phosphodiesterase; STEMI, ST elevation myocardial infarction.

of currently approved antiplatelet drugs include a narrow therapeutic window and limited efficacy. An overview of the current Food and Drug Administration (FDA)-approved antiplatelet therapies as well as those in development will be discussed in this review.

\section{$\mathrm{P} 2 \mathrm{Y}$ receptor antagonists}

The P2Y receptors are G-protein-coupled (GPCR) purinergic receptors belonging to the $\mathrm{P} 2$ family. Two receptors, $\mathrm{P} 2 \mathrm{Y}_{1}$ and $\mathrm{P} 2 \mathrm{Y}_{12}$, are present in the platelet. $\mathrm{P} 2 \mathrm{Y}_{1}$ is a $\mathrm{G}_{\mathrm{q}}$ coupled GPCR, while $\mathrm{P} 2 \mathrm{Y}_{12}$ is coupled to $\mathrm{G}_{\mathrm{i} 2}$. Activation of $\mathrm{P} 2 \mathrm{Y}_{1}$ signals phospholipase $\beta$, leading to DAG formation, calcium mobilization, and eventually PKC and CalDAG-GEF activation. ${ }^{1}$ In contrast, $\mathrm{P} 2 \mathrm{Y}_{12}$ activation inhibits adenylyl cyclase, activates phosphoinositide 3-kinase, ${ }^{2}$ the small GTPase Rap $1,{ }^{3}$ and activation of $\alpha \operatorname{IIb} \beta 3 .{ }^{4}$

Ticlopidine (Ticlid ${ }^{\circledR}$; Roche, Basel, Switzerland) is a first generation thienopyridine that requires cytochrome $\mathrm{P} 450$ (CYP) $1 \mathrm{~A}$ metabolism prior to exerting its irreversible antagonistic effects on platelet reactivity via the $\mathrm{P} 2 \mathrm{Y}_{12}$ receptor. $^{5}$ Early experimental observations showed agonist-induced platelet aggregation was intermittently inhibited by ticlopidine. ${ }^{6,7}$ Studies with ticlopidine, however, exhibit off-target effects mediated by the inhibition of intracellular calcium mobilization. ${ }^{8}$ Maximal inhibition of platelet aggregation is observed 3-5 days post administration of ticlopidine. ${ }^{9}$ The delayed onset of antiplatelet effects is a consequence of metabolism of the pro-drug. ${ }^{6}$ Clinical trials (CATS and TASS studies) have shown ticlopidine to be more effective than aspirin alone, ${ }^{10,11}$ but exhibiting significant off-target effects including minor bleeding with hemorrhagic events observed in less than $1 \%$ of subjects studied. Additionally, ticlopidine-treated patients typically discontinue treatment due to a variety of secondary adverse events including diarrhea, skin rash, and neutropenia. ${ }^{10,12}$

Clopidogrel (Plavix ${ }^{\circledR}$, Bristol-Myers Squibb, New York City, NY), a second generation oral thienopyridine, also requires metabolism of a pro-drug by the CYP2C19. The active metabolite, which is a highly labile compound, irreversibly binds to and inhibits the $\mathrm{P} 2 \mathrm{Y}_{12}$ receptor through a disulfide bridge. The CURE trial has shown the clinical benefit of the dual clopidogrel-aspirin therapy compared with aspirin alone by significantly reducing mortality and nonfatal MI or stroke in patients with unstable angina; however, the dual regimen was associated with an increase in bleeding compared with placebo. ${ }^{13,14}$ The CAPRIE trial, which evaluated the efficacy of clopidogrel monotherapy compared with dual therapy of clopidogrel plus aspirin, showed clopidogrel treatment results in a reduction of primary endpoints. ${ }^{15}$ Evidence of poor metabolizers for clopidogrel has helped to explain the reduced function in patients with an altered CYP2C19 allele. ${ }^{16}$ Poor metabolizers of clopidogrel have diminished platelet inhibition resulting in a higher rate of adverse cardiovascular events than noncarriers. ${ }^{17}$ 
Prasugrel $\left(\right.$ Effient $^{\circledR}$, Eli Lilly and Company, Indianapolis, IN) is a third-generation thienopyridine, chemically distinct from clopidogrel. In-vivo and in-vitro pharmacological studies have demonstrated that this adenosine triphosphate (ATP) analog selectively and irreversibly inhibits adenosine diphosphate (ADP)-induced aggregation to a greater degree than clopidogrel. ${ }^{18}$ The irreversible binding is thought to be due to the disulfide binding between the reactive thiol group of the active metabolite and the cysteine residue of the $\mathrm{P} 2 \mathrm{Y}_{12}$ receptor. ${ }^{19-21}$ Prasugrel is an orally available pro-drug that requires active transformation via the CYP450 along with esterases. ${ }^{22}$ Activation of the pro-drug requires CYP3 A4 and CYP2B6 ${ }^{23}$ Clinical studies have verified that inhibition of platelet aggregation is more effective with prasugrel compared with clopidogrel after a single dose in healthy subjects. ${ }^{23}$ Furthermore, subjects who responded poorly to clopidogrel showed greater platelet-induced inhibition in response to prasugrel. ${ }^{23,24}$ Further, assessment of secondary endpoints favors prasugrel due to lower incidences of cardiovascular death, nonfatal MI, and rehospitalization due to recurrent ischemia.

Ticagrelor (Brillinta ${ }^{\circledR}$, AstraZeneca, London, UK), an oral cyclopentyl-triazolo-pyrimidine analog, unlike thienopyridines, is a direct and reversible inhibitor of the $\mathrm{P} 2 \mathrm{Y}_{12}$ receptor that is activated from its pro-drug by CYP3 $\mathrm{A} .^{25}$ Ticagrelor exerts its action via binding to the $\mathrm{P} \mathrm{Y}_{12}$ receptor at a site distinct from the ADP binding site, thus making it an allosteric inhibitor. ${ }^{25} \mathrm{As}$ a consequence of P2 $\mathrm{Y}_{12}$ inhibition, ATP is converted to cyclic monophosphate, vasodilator-stimulated phospoprotein is dephosphorylated, and activation of PI3-K is inhibited. ${ }^{26}$ The PLATO trial compared ticagrelor with clopidogrel in which the primary composite endpoints, stroke, MI, cardiovascular death, and stent thrombosis, were reduced in patients with acute coronary syndromes (ACS) (with or without ST-elevation MI). ${ }^{27}$ The benefit of ticagrelor appears to be attenuated in patients with lower bodyweight and those not taking lipid-lowering drugs in North American groups relative to comparative studies elsewhere. ${ }^{28}$ There is no significant difference in major bleeding between the two agents; however, spontaneous (noncoronary artery bypass grafts) or nonproceduralrelated bleeding is increased with ticagrelor. Additionally, off-target effects of dyspnea and asymptomatic ventricular pauses are associated with ticagrelor use. ${ }^{28,29}$ In general, ticagrelor has so far proven superior to current treatment regimens, including a rapid onset of action, acceptable safety profile, and effectiveness in reducing the primary endpoints in ACS patients.
Elinogrel (PRT060128, Novartis, Basel, Switzerland/ Portola Pharmaceuticals, South San Francisco, CA) is a direct-acting reversible $\mathrm{P} 2 \mathrm{Y}_{12}$ receptor inhibitor that is currently undergoing clinical investigation (INNOVATE-PCI) for efficacy and safety in patients undergoing percutaneous coronary intervention (PCI) (see Table 2).$^{30}$ Preclinical data show that intravenous or orally administered elinogrel is superior to clopidogrel and has minimal effect on bleeding times. ${ }^{31}$ In addition, a single dose of elinogrel has been shown to overcome high platelet reactivity in patients undergoing PCI who were nonresponsive to clopidogrel. ${ }^{31}$ Elinogrel, while still in clinical development for safety and efficacy assessment in patients, shows promise as a next generation $\mathrm{P} 2 \mathrm{Y}_{12}$ antagonist.

Cangrelor (ARC-69931MX, The Medicines Company, Parsippany, NJ) is an intravenous nontheinopyridine and reversible $\mathrm{P}_{2} \mathrm{Y}_{12}$ inhibitor. Like prasugrel and ticagrelor, cangrelor showed a more rapid onset of action and greater degree of platelet inhibition than clopidogrel. Recent evaluations of the inhibitor in the CHAMPION-PCI and CHAMPION-PLATFORM trials were stopped early due to its lack of apparent differences in the primary endpoint of death, MI, or ischemia-driven revascularization 48 hours after PCI. ${ }^{32}$ Also, the rate of major bleeding in patients undergoing PCI was higher with cangrelor compared with clopidogrel in both studies. ${ }^{33}$

Table 2 Antiplatelet drugs under development

\begin{tabular}{lll}
\hline Drug & Target & Stage of development \\
\hline Elinogrel & P2YI2 receptor & Phase II \\
Cangrelor & P2YI2 receptor & Phase III \\
BX 667 & P2YI2 receptor & Preclinical \\
Vorapaxor (SXH 530348) & PARI & Phase III \\
Atopaxar (E5555) & PARI & Phase II \\
SI8886 (Terutroban) & TP $\alpha$ & Phase III \\
Z-335 & TP $\alpha$ & Phase I \\
BM-573 & TP $\alpha$ & Preclinical \\
h6B4-Fab & GPIb & Preclinical \\
GPGP-290 & GPIb $\alpha$ & Preclinical \\
SZ2 & GPIb $\alpha$ & Preclinical \\
PR-15 (Revacept) & GPVI & Phase I completed \\
DZ-697b & GPVI & Phase I completed \\
AJW200 & VWF & Phase I \\
ARCI779 & VWF & Phase II \\
ARCI5I05 & VWF & Preclinical \\
ALX-008I & VWF & Phase II \\
ALX-068I & vWF & Phase II \\
82D6 A3 & vWF & Preclinical \\
Z4 A5 & GPIIb-IIla & Preclinical \\
DG-04I & PGE 2 & Phase II \\
\hline
\end{tabular}


BX 667 is an orally active reversible $\mathrm{P} 2 \mathrm{Y}_{12}$ receptor antagonist that is metabolized by esterases to form the carboxylic active form, BX 048. ${ }^{34}$ In-vitro, ADP-induced aggregation is potently inhibited by BX 667 . Additionally, administration of BX 667 results in a rapid and sustained inhibition aggregation..$^{35}$ This observation is also supported by the intravenous BX 048 and oral BX 667 administration in rat arteriovenous-shunt model which showed a similar pharmacodynamic relationship between the plasma concentration of BX 048 and thrombus inhibition. ${ }^{34}$ This antagonist has yet to be evaluated in healthy human subjects.

\section{Glycoprotein antagonists $\alpha$ llb $\beta 3$ antagonists}

Glycoprotein GPIIbIIIa $(\alpha \operatorname{IIb} \beta 3)$ is the most abundant integrin on the platelet surface. ${ }^{36} \alpha \operatorname{IIb} \beta 3$ is known to be involved in both inside-out or outside-in platelet signaling. The inside-out signaling in platelet activation involves the various signaling pathways that converge into a common signaling endpoint that leads to the activation of integrin $\alpha \operatorname{IIb} \beta 3 .{ }^{37}$ Ligand binding of fibrinogen or von Willebrand factor ( $\mathrm{Vwf}$ ) to $\alpha \operatorname{IIb} \beta 3$ mediates platelet adhesion and aggregation, triggers outside-in integrin activation and results in additional granule secretion, stabilization of platelet adhesion, aggregation, and clot retraction. ${ }^{37}$

Abciximab (ReoPro ${ }^{\circledR}$; Eli Lilly) is an antibody developed from the murine human chimera c7E3 Fab, which targets the integrin $\alpha \operatorname{IIb} \beta 3,{ }^{38}$ preventing integrin binding to fibrinogen and Vwf. Abciximab rapidly binds with high affinity and has a slow rate of dissociation from its target. ${ }^{39}$ In addition, abciximab binds with high affinity to $\alpha_{v} \beta 3$

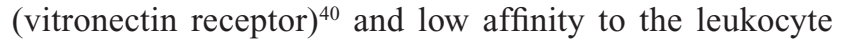
MAC-1 receptor. ${ }^{41}$ Initial intravenous administration enables rapid onset of platelet inhibition. ${ }^{42}$ As abciximab has an extremely short half-life, ${ }^{43}$ platelet aggregation returns to baseline levels within 12-24 hours following discontinuation of therapy. ${ }^{44,45}$ Interestingly, the ISAR-REACT trial demonstrated no additional benefit of abciximab over placebo in the reduction of ischemic complications or mortality. ${ }^{43,46}$ Similarly, among diabetic patients without elevated troponin levels undergoing elective PCI, no difference was observed in primary endpoint events between abciximab and placebo/ clopidogrel groups. ${ }^{47}$ Conversely, in patients with elevated troponin levels, the incidence of mortality and recurrent ischemic complications was significantly reduced with abciximab. ${ }^{48}$ Careful monitoring must be accompanied with the administration of abciximab as bleeding and thrombocytopenia have been observed. ${ }^{49-51}$
Eptifibatide (Integrilin ${ }^{\circledR}$, Millenium Pharmaceuticals, Cambridge, MA/Schering-Plough, Kenilworth, NJ) is a cyclic heptapeptide derived from snake venom that contains a KGD (lysine-glycine-aspartic acid) sequence which selectively recognizes $\alpha I I \beta 3 .{ }^{52}$ The IMPACT-II study showed that a single loading dose followed by continuous infusion for 20-24 hours only resulted in $50 \% \alpha \mathrm{IIb} \beta 3$ receptor blockade; thus, limited benefits and efficacy through eptifibatide were observed. ${ }^{53}$ The ESPRIT trial, however, which utilized intravenous administration of a double bolus ${ }^{54}$ followed by maintenance infusion, significantly reduced the 30 days incidence of death, MI, and target vessel revascularization, ${ }^{55}$ establishing the clinical efficacy for this drug. These observations were confirmed in the PURSUIT trial, which showed an absolute reduction in the 30-day incidence of death and MI on eptifibatide. ${ }^{56}$ Despite the reduction in mortality, the ACUITY trial also showed an increase incidence of major bleeding in patients with ACS undergoing PCI. ${ }^{57,58}$

Tirofiban (Aggrastat ${ }^{\circledR}$, Merck, Whitehouse Station, NJ) is a tyrosine-derivative nonpeptide mimetic reversible inhibitor of $\alpha \operatorname{IIb} \beta 3$ that specifically and competitively binds to the receptor. Treatment with tirofiban in combination with aspirin and heparin in patients with ACS significantly reduced the 30-day post-treatment incidence of death, MI, or recurrent ischemia. ${ }^{59}$ Further, tirofiban was superior for ACS patients recovering from invasive coronary angiography. ${ }^{59}$ As for the use of tirofiban as an adjunct to PCI, tirofiban was shown to be inferior to abciximab in the RESTORE and TARGET trials where the incidence of composite death, nonfatal MI, and urgent target vessel revascularization were higher with tirofiban or abciximab at 30 days. ${ }^{60}$

Z4 A5 is a novel $\alpha \mathrm{IIb} \beta 3$ peptide antagonist that is currently in development. This antagonist has been shown to inhibit platelet-induced aggregation and thrombi formation. Additionally, when Z4 A5 was examined along with heparin and/ or aspirin in the rabbit arteriovenous shunt thrombosis model, it was shown to be an effective antithrombotic agent when administered with aspirin. ${ }^{61}$ The pharmacodynamics and pharmacokinetics in humans are currently under investigation. ${ }^{61}$

\section{Additional glycoprotein antagonists}

Additional glycoprotein targets have received a fair amount of attention in the drive to develop novel approaches for antiplatelet intervention. The Vwf, a multimeric glycoprotein that acts as a bridging element between damaged endothelial sites and the glycoprotein receptors on platelets, is one such target. The $\mathrm{A} 1$ and $\mathrm{A} 3$ domains of $\mathrm{Vwf}$ bind to collagen, while the A1 domain is bound to the GPIb-IX-V platelet receptor 
complex. ${ }^{62,63} \mathrm{Vwf}$ also binds to active $\alpha \mathrm{IIb} \beta 3$ on the platelet surface. Interactions between $\alpha \operatorname{IIb} \beta 3$ and Vwf contribute to the final, irreversible binding of platelets to the subendothelium and play a leading role in platelet aggregation. ${ }^{64}$ A second target receiving attention as a potential site for antiplatelet therapy is the collagen receptor glycoprotein VI (GPVI). The collagen-GPVI interaction triggers subsequent tyrosine phosphorylation of the immunoreceptor tyrosinebased activation motif of the Fc receptor $\gamma$ chain, activating the Syk kinases pathway, LAT, SLP-76, and phospholipase $\mathrm{C} \gamma 2,{ }^{65}$ resulting in platelet activation or aggregation.

\section{Vwf antagonists}

AJW200 is an IgG4 humanized monoclonal antibody to Vwf which has been shown to specifically inhibit high-shearstress-induced platelet aggregation in a concentration-dependent manner in vitro in blood from human volunteers. ${ }^{66}$

ARC1779 (Archemix Corp, San Francisco, CA) is an aptamer-based antagonist. This second generation nucleaseresistant aptamer is conjugated to a $20-\mathrm{Kda}$ polyethylene glycol and binds with high affinity to the active Vwf A1-domain and inhibits Vwf-dependent platelet aggregation. ${ }^{67} \mathrm{~A}$ Phase II trial demonstrated that continuous infusion of ARC1779 effectively increased platelet counts in critically ill thrombotic thrombocytopenic purpura patients by preventing platelet aggregation and loss of platelets. Cessation of ARC1779 infusion resulted in platelet count reduction and progression of thrombotic thrombocytopenic purpura-related organ damage. ${ }^{68}$ This drug is currently under clinical investigation.

Other Vwf antagonists in clinical development or investigations include ARC15105, ALX-0081 (Ablynx), ALX-0681, and 82D6 A3. ARC15105 is a chemically advanced aptamer with assumed higher affinity to Vwf, but less specific inhibitor of Vwf-dependent platelet aggregation than ARC1779, based on ex-vivo trials. ${ }^{69}$ The preclinical and clinical trials have shown that ALX-0081, a bivalent humanized nanobody that recognizes the Glycoprotein $\mathrm{Ib}$ (GPIb) binding site of Vwf, is a potent and safe inhibitor of Vwf-mediate platelet aggregation over a wide range of doses when administered in combination with aspirin, heparin, and clopidogrel. ALX0081 is currently under investigation in PCI patients in a Phase II trial. 82D6 A3, a monoclonal antibody directed against amino acids Arg-963, Pro-981, Asp-1009, Arg-1016, Ser-1020, Met-1022, and His-1023 of the Vwf A3 domain, ${ }^{70}$ was shown to result in complete inhibition of Vwf binding to collagen during the first 3 days after stent implantation in baboons. ${ }^{71}$ Further trials will need to follow to verify 82D6 A3 efficacy, safety, and tolerability.

\section{GPVI receptor antagonists}

PR-15 (Revacept ${ }^{\circledR}$, ABX-CRO/Medifacts GmbH, Goerlitz, Saxony, Germany) is a soluble, dimeric glycoprotein (GPVI)-Fc that has been shown to adhere to exposed collagen in endothelial lesions preventing the binding to platelet GPVI receptors. Collagen-induced human platelet adhesion or plaque formation were significantly reduced with pretreatment of soluble GPVI-Fc. ${ }^{72,73}$ Similarly, infusion of GPVI-Fc was shown to virtually abolish stable arrest and aggregation of platelets following vascular injury in mice. ${ }^{65}$ Subsequently, a Phase I clinical trial demonstrated that intravenous administration of PR-15 is safe and well tolerated by healthy volunteers. ${ }^{74}$

DZ-697b is an orally active collagen and ristocetin inhibitor. Safety and efficacy have been assessed in a Phase I trial which showed potential benefits such that bleeding time was substantially shortened compared with clopidogrel treatment. ${ }^{75}$ DZ-697b is currently under clinical investigation.

\section{GPIb receptor antagonists}

Novel targets still under investigation include h6B4-Fab, GPGP-290, and SZ2. h6B4-Fab is a murine monoclonal antibody, derived from the humanized Fab fragment of 6B4 targeting GPIb $\alpha$ and neutralizes the binding site of the Vwf A1 domain. ${ }^{76,77} 6 \mathrm{~B} 4$ has been shown to inhibit platelet adhesion by competing with Vwf for binding to GPIbo under high-shear conditions. Moreover, preliminary data show 6B4 has no effect on platelet count or bleeding times in vivo in baboons, but dose- and time-dependently inhibited ristocetininduced platelet aggregation. ${ }^{78}$ GPG-290 is a recombinant, chimeric antibody purified from Chinese hamster ovary cell culture that contains the amino-terminal 290 amino acids of GPIb $\alpha$ linked to the human IgG1. GPG-290 treated dogs were shown to exhibit prolonged bleeding compared with the clopidogrel-treated control, despite the prevention of coronary artery thrombosis. ${ }^{79} \mathrm{SZ} 2$, a monoclonal antibody developed against GPIb $\alpha$, has also been shown to inhibit both ristocetin- and botrocetin-induced platelet aggregation in vitro. ${ }^{80}$ Preclinical investigations are still underway to determine the in-vivo efficacy of SZ2.

\section{Phosphodiesterase antagonists}

Platelets express three phosphodiesterase (PDE) isoenzymes, PDE 2, 3, and 5. PDEs regulate the levels of 3,5'-cyclic adenosine monophosphate (Camp) and 3',5'-cyclic guanosine monophosphate (Cgmp) by catalyzing the hydrolysis of Camp and Cgmp to inactive 5'-AMP and 5'-GMP, respectively. ${ }^{81}$ Platelet activation relies on degradation of Camp 
and Cgmp; hence regulating these secondary messengers is fundamental in regulating platelet activation and thrombosis.

Cilostazol (Pletal ${ }^{\circledR}$, Otsuka Pharmaceutical Co, Tokyo, Kapan) is a type III PDE (PDE3) selective oral inhibitor. ${ }^{82}$ Liu and colleagues have shown that cilostazol enhances the interstitial concentration of adenosine in several in-vitro and in-vivo models ${ }^{83}$ by inhibiting adenosine uptake. This in turn stimulates $A_{2}$ receptors, which further increases Camp levels. As a result, platelet-induced aggregation is reversibly inhibited by cilostazol. ${ }^{84}$ Cilostazol is extensively metabolized by CYP3 A4, while CYP2C19 is also shown to have a minor role in cilostazol metabolism. ${ }^{85}$ Cilostazol is safe and effective in reducing the incidence of repeated revascularization after PCI and risk of restenosis; however, this drug does not show superiority in reducing the primary composite endpoints of adverse cardiovascular events after drug-elution stent implantation. ${ }^{86}$ Despite the functional implications of adjunctive treatment with cilostazol compared with standard aspirin and clopidogrel treatment, as shown in the OPTIMUS-2 study, the accompanied side effects (headaches, gastrointestinal symptoms, and skin rash) often lead to the discontinuation of the drug. ${ }^{87}$

Dipyridamole (Aggrenox ${ }^{\circledR}$, Boehringer Ingelheim, Ingelheim, Germany) is a pyridopyrimidine derivative with both antiplatelet and vasodilator properties. ${ }^{88}$ Similar to cilostazol, dipyridamole inhibits cyclic nucleotide phosphodiesterase and blocks adenosine uptake, which results in increased Camp. ${ }^{89}$ The ESPS-2 and ESPRIT trials showed that dual treatment of dipyridamole and aspirin reduced risk of stroke or death by $37 \%$ compared with aspirin alone..$^{90,91}$ Based on the ESPRIT and ESPS-2 trials, dipyridamole has been FDA approved for stroke prevention. ${ }^{91}$

\section{Thromboxane $A_{2}$ receptor antagonists}

Platelets express the thromboxane receptor $\alpha$ (TP $\alpha)$, a GPCR that is coupled to $G_{q}$ and $G_{12 / 13}$ and signals platelet activation through a number of intracellular pathways which converge to reinforce primary platelet activation through thrombin or collagen. $^{92}$

$\mathrm{S} 18886$ (terutroban) is an oral reversible inhibitor of TP $\alpha$. In preclinical studies, S18886 dose-dependently prolonged occlusive thrombus formation in animal models, but did not alter the size of the myocardial infarct size in the ischemiaperfusion model. S18886 and clopidogrel were effective in preventing occlusive thrombus formation with a moderate increase in bleeding time. ${ }^{93}$ Subsequently, however, in the
Phase III clinical trial (PERFORM), S18886 did not meet the predefined criteria for noninferiority since S18886 and aspirin had similar rates of protection without safety advantages for S18886. ${ }^{94}$

Z-335 ((+/-)-sodium[2-(4-chlorophenylsulfonyl-aminomethyl)indan-5-yl]acetate monohydrate) is an oral TP $\alpha$ antagonist that has previously been shown to dose-dependently inhibit the specific binding of $\left[{ }^{3} \mathrm{H}\right] \mathrm{SQ}-29548$ (TP $\alpha$ inhibitor) to human and guinea pig platelet membranes. ${ }^{95}$ In healthy male Japanese volunteers, Z-335 inhibited U46619-induced platelet aggregation within 2 hours of administration. ${ }^{96}$

BM-573, another investigational inhibitor that targets TP $\alpha$, has been shown to halt the progression of atherosclerosis in low-density lipoprotein receptor deficient mice. ${ }^{97}$ Preclinical models have shown that arachidonic acid-induced aggregation is completely inhibited in the presence of BM-573 ${ }^{98}$ and clinical studies on this compound are currently ongoing.

\section{Thrombin receptor antagonists}

Thrombin activates human platelets via two protease activated receptors (PARs), PAR1 and PAR4. PAR activation leads to a diverse range of pro-thrombotic signaling events mediated through $\mathrm{G}_{\mathrm{q}}, \mathrm{G}_{12 / 13}$, and possibly $\mathrm{G}_{\mathrm{i}}$, resulting in phospholipase $\beta$ activation, Rho activation, and adenyl cyclase inhibition, respectively. PAR activation requires thrombin cleavage of the amino terminus of the receptor, revealing a tethered ligand. While it has been challenging to develop an inhibitor that can directly compete with the endogenous tethered ligand, development of PAR1 inhibitors as a therapeutic target to minimize uncontrolled platelet activation has recently been investigated.

SCH 530348 (Vorapaxar ${ }^{\circledR}$, Merck and Co, Whitehouse Station, NJ) is an orally active synthetic analog of himbacine $^{99}$ that competitively binds with high affinity to the PAR1. Previous in-vitro assays show SCH 530348 inhibited thrombin- and thrombin receptor activating peptide-induced platelet aggregation, without affecting the aggregation induced by ADP, U46619, or collagen. In addition, SCH 530348 did not affect the prothrombin and activated partial thromboplastin time, suggesting that bleeding time may not be increased. Pre-clinically, cynomolgus monkeys treated with SCH 530348 alone or in addition with aspirin and clopidogrel, showed no increase in bleeding times. ${ }^{100}$ The TRA-PCI study verified that addition of SCH 530348 to standard antiplatelet therapy (aspirin and clopidogrel) was not associated with increases in thrombolysis in MI (TIMI) 
or bleeding compared with the control group. ${ }^{101}$ The Phase III clinical trials TRA-CER and TRA $2^{\circ} \mathrm{P}$-TIMI, which sought to assess the impact of vorapaxar on cardiovascular death, MI, stroke, and recurrent vascular events in patients with established coronary, cerebral, or peripheral atherosclerosis ${ }^{102}$ failed due to unforeseen intracranial bleeding. ${ }^{102}$

Preclinical trials showed that oral administration of the PAR1 antagonist, E5555 (Atopaxar®, Eisai Co Ltd, Tokyo, Japan), significantly prolonged bleeding times in guinea pigs. ${ }^{103}$ Further, PECAM-1, active $\alpha \mathrm{IIb} \beta 3$, GPIb, thrombospondin, and vitronectin expression were significantly reduced by E5555 in whole blood flow cytometry. Clinical studies have shown that E5555 attenuated thrombin-induced but not ADP-induced platelet aggregation. ${ }^{104,105}$

Additional PAR-1 antagonists SCH 205831 and SCH 602539 are still under investigation. Preliminary data show SCH 205831 derived from himbacine inhibited platelet deposition in baboons with arteriovenous-shunt thrombosis. Similarly, SCH 602539 inhibited thrombosis in a dose-dependent manner in the Folts model of thrombosis in anesthetized cynomolgus monkeys. ${ }^{106}$ These compounds continue to be developed in preclinical models.

\section{Conclusion}

Significant progress has been made in advancing our understanding of how platelet activation directly regulates thrombus formation in the vessel leading to occlusive thrombi and stroke. However, a continued need for the development of new antiplatelet therapies exists as the risk for MI, stroke, and death, remain a persistent problem for individuals suffering from cardiovascular disease. Further, while aspirin continues to be the first line of pharmacological intervention in antiplatelet therapy, the risk of bleeding is significantly exacerbated by its irreversible action coupled to the additional regimen of dual therapy often employed to minimize thrombotic events. In hopes of reducing prolonged bleeding or myocardial infarct events, newer compounds continue to be developed to target alternative sites in the platelet. The successful implementation of these strategies may significantly reduce the morbidity and mortality in cardiovascular disease due to unwanted platelet activation as well as excessive bleeding due to traditional approaches. Even with the newer antiplatelet drugs entering the market in the near future, we are faced with the realization that activation of the platelet involves an increasingly complex signaling network. Hence, new frontiers will need to be explored which will take advantage of this signaling to reveal novel therapeutic targets with diminished off-target effects.

\section{Acknowledgments}

This work was supported in part by the National Institutes of Health National Heart, Lung, and Blood Institutes grant HL089457 (MH).

\section{Disclosure}

The authors report no conflicts of interest in this work.

\section{References}

1. Cohen S, Braiman A, Shubinsky G, Isakov N. Protein kinase C-theta in platelet activation. FEBS Lett. 2011;585(20):3208-3215.

2. Trumel C, Payrastre B, Plantavid M, et al. A key role of adenosine diphosphate in the irreversible platelet aggregation induced by the PAR1-activating peptide through the late activation of phosphoinositide 3-kinase. Blood. 1999;94(12):4156-4165.

3. Jung SM, Ohnuma M, Watanabe N, Sonoda M, Handa M, Moroi M. Analyzing the mechanism of Rap1 activation in platelets: Rap1 activation is related to the release reaction mediated through the collagen receptor GPVI. Thromb Res. 2006;118(4):509-521.

4. Kim S, Kunapuli SP. P2Y12 receptor in platelet activation. Platelets. 2011;22(1):54-58.

5. Schror K. The basic pharmacology of ticlopidine and clopidogrel Platelets. 1993;4(5):252-261.

6. McTavish D, Faulds D, Goa KL. Ticlopidine. An updated review of its pharmacology and therapeutic use in platelet-dependent disorders. Drugs. 1990;40(2):238-259.

7. Albers GW. Role of ticlopidine for prevention of stroke. Stroke. 1992;23(6):912-916.

8. Derian CK, Friedman PA. Effect of ticlopidine ex vivo on platelet intracellular calcium mobilization. Thromb Res. 1988;50(1):65-76.

9. Cattaneo M. New P2Y(12) inhibitors. Circulation. 2010;121(1): 171-179.

10. Gent M, Blakely JA, Easton JD, et al. The Canadian American Ticlopidine Study (CATS) in thromboembolic stroke. Lancet 1989;1(8649):1215-1220.

11. Hass WK, Easton JD, Adams HP Jr, et al. A randomized trial comparing ticlopidine hydrochloride with aspirin for the prevention of stroke in high-risk patients. Ticlopidine Aspirin Stroke Study Group. $N$ Engl J Med. 1989;321(8):501-507.

12. Quinn MJ, Fitzgerald DJ. Ticlopidine and clopidogrel. Circulation. 1999;100(15):1667-1672.

13. Mehta SR, Yusuf S, Peters RJ, et al. Effects of pretreatment with clopidogrel and aspirin followed by long-term therapy in patients undergoing percutaneous coronary intervention: the PCI-CURE study. Lancet. 2001;358(9281):527-533.

14. Yusuf S, Zhao F, Mehta SR, Chrolavicius S, Tognoni G, Fox KK Effects of clopidogrel in addition to aspirin in patients with acute coronary syndromes without ST-segment elevation. $N$ Engl $J$ Med. 2001;345(7):494-502.

15. A randomised, blinded, trial of clopidogrel versus aspirin in patients at risk of ischaemic events (CAPRIE). CAPRIE Steering Committee. Lancet. 1996;348(9038):1329-1339.

16. Mega JL, Close SL, Wiviott SD, et al. Cytochrome p-450 polymorphisms and response to clopidogrel. $N$ Engl J Med. 2009;360(4):354-362.

17. Simon T, Verstuyft C, Mary-Krause M, et al. Genetic determinants of response to clopidogrel and cardiovascular events. $N$ Engl J Med. 2009;360(4):363-375.

18. Sugidachi A, Asai F, Ogawa T, Inoue T, Koike H. The in vivo pharmacological profile of CS-747, a novel antiplatelet agent with platelet ADP receptor antagonist properties. Br J Pharmacol. 2000;129(7):1439-1446.

19. Sugidachi A, Asai F, Yoneda K, et al. Antiplatelet action of R-99224, an active metabolite of a novel thienopyridine-type G(i)-linked P2T antagonist, CS-747. Br J Pharmacol. 2001;132(1):47-54. 
20. Hasegawa M, Sugidachi A, Ogawa T, Isobe T, Jakubowski JA, Asai F. Stereoselective inhibition of human platelet aggregation by R-138727, the active metabolite of CS-747 (prasugrel, LY640315), a novel P2Y12 receptor inhibitor. Thromb Haemost. 2005;94(3):593-598.

21. Savi P, Pereillo JM, Uzabiaga MF, et al. Identification and biological activity of the active metabolite of clopidogrel. Thromb Haemost. 2000;84(5):891-896.

22. Farid NA, Payne CD, Small DS, et al. Cytochrome P450 3 A inhibition by ketoconazole affects prasugrel and clopidogrel pharmacokinetics and pharmacodynamics differently. Clin Pharmacol Ther. 2007;81(5):735-741.

23. Brandt JT, Payne CD, Wiviott SD, et al. A comparison of prasugrel and clopidogrel loading doses on platelet function: magnitude of platelet inhibition is related to active metabolite formation. Am Heart J. 2007;153(1):66.e9-16.

24. Montalescot G, Wiviott SD, Braunwald E, et al. Prasugrel compared with clopidogrel in patients undergoing percutaneous coronary intervention for ST-elevation myocardial infarction (TRITON-TIMI 38): doubleblind, randomised controlled trial. Lancet. 2009;373(9665):723-731.

25. Birkeland K, Parra D, Rosenstein R. Antiplatelet therapy in acute coronary syndromes: focus on ticagrelor. J Blood Med. 2010;1:197-219.

26. Anderson SD, Shah NK, Yim J, Epstein BJ. Efficacy and safety of ticagrelor: a reversible P2Y12 receptor antagonist. Ann Pharmacother. 2010;44(3):524-537.

27. Mahaffey KW, Wojdyla DM, Carroll K, et al. Ticagrelor compared with clopidogrel by geographic region in the Platelet Inhibition and Patient Outcomes (PLATO) trial. Circulation. 2011;124(5):544-554.

28. Wallentin L, Becker RC, Budaj A, et al. Ticagrelor versus clopidogrel in patients with acute coronary syndromes. $N$ Engl $J$ Med. 2009;361(11):1045-1057.

29. Cannon CP, Husted S, Harrington RA, et al. Safety, tolerability, and initial efficacy of AZD6140, the first reversible oral adenosine diphosphate receptor antagonist, compared with clopidogrel, in patients with non-ST-segment elevation acute coronary syndrome: primary results of the DISPERSE-2 trial. J Am Coll Cardiol. 2007;50(19):1844-1851.

30. Leonardi S, Rao SV, Harrington RA, et al. Rationale and design of the randomized, double-blind trial testing IntraveNous and Oral administration of elinogrel, a selective and reversible P2Y(12)-receptor inhibitor, versus clopidogrel to eVAluate Tolerability and Efficacy in nonurgent Percutaneous Coronary Interventions patients (INNOVATE-PCI). Am Heart J. 2010;160(1):65-72.

31. Gurbel PA, Bliden KP, Antonino MJ, et al. The effect of elinogrel on high platelet reactivity during dual antiplatelet therapy and the relation to CYP2C19*2 genotype: first experience in patients. J Thromb Haemost. 2010;8(1):43-53.

32. Harrington RA, Stone GW, McNulty S, et al. Platelet inhibition with cangrelor in patients undergoing PCI. $N$ Engl J Med. 2009;361(24): 2318-2329.

33. Bhatt DL, Lincoff AM, Gibson CM, et al. Intravenous platelet blockade with cangrelor during PCI. N Engl J Med. 2009;361(24):2330-2341.

34. Wang YX, Vincelette J, da Cunha V, et al. A novel P2Y(12) adenosine diphosphate receptor antagonist that inhibits platelet aggregation and thrombus formation in rat and dog models. Thromb Haemost. 2007;97(5):847-855.

35. Post JM, Alexander S, Wang YX, et al. Novel P2Y12 adenosine diphosphate receptor antagonists for inhibition of platelet aggregation (II): pharmacodynamic and pharmacokinetic characterization. Thromb Res. 2008;122(4):533-540.

36. Gogstad GO, Brosstad F, Krutnes MB, Hagen I, Solum NO. Fibrinogenbinding properties of the human platelet glycoprotein Iib- = IIIa complex: a study using crossed-radioimmunoelectrophoresis. Blood. 1982;60(3):663-671.

37. Li Z, Delaney MK, O’Brien KA, Du X. Signaling during platelet adhesion and activation. Arterioscler Thromb Vasc Biol. 2010;30(12): 2341-2349.

38. Kristensen SD, Wurtz M, Grove EL, et al. Contemporary use of glycoprotein Iib/IIIa inhibitors. Thromb Haemost. 2012;107(2):215-224.
39. Wagner CL, Mascelli MA, Neblock DS, Weisman HF, Coller BS, Jordan RE. Analysis of GPIIb/IIIa receptor number by quantification of 7E3 binding to human platelets. Blood. 1996;88(3):907-914.

40. Tam SH, Sassoli PM, Jordan RE, Nakada MT. Abciximab (ReoPro, chimeric 7E3 Fab) demonstrates equivalent affinity and functional blockade of glycoprotein Iib/IIIa and alpha(v)beta3 integrins. Circulation. 1998;98(11):1085-1091.

41. Simon DI, Xu H, Ortlepp S, Rogers C, Rao NK. 7E3 monoclonal antibody directed against the platelet glycoprotein Iib/IIIa cross-reacts with the leukocyte integrin Mac-1 and blocks adhesion to fibrinogen and ICAM-1. Arterioscler Thromb Vasc Biol. 1997;17(3):528-535.

42. Kleiman NS, Raizner AE, Jordan R, et al. Differential inhibition of platelet aggregation induced by adenosine diphosphate or a thrombin receptor-activating peptide in patients treated with bolus chimeric 7E3 Fab: implications for inhibition of the internal pool of GPIIb/IIIa receptors. J Am Coll Cardiol. 1995;26(7):1665-1671.

43. Kastrati A, Mehilli J, Schuhlen H, et al. A clinical trial of abciximab in elective percutaneous coronary intervention after pretreatment with clopidogrel. N Engl J Med. 2004;350(3):232-238.

44. Lim GB. Antiplatelet therapy: intracoronary abciximab during PCI for STEMI. Nat Rev Cardiol. 2011;9(5):258.

45. Van de Werf F, Ardissino D, Bueno H, et al. Acute coronary syndromes: considerations for improved acceptance and implementation of management guidelines. Expert Rev Cardiovasc Ther. 2012;10(4):489-503.

46. Schomig A, Schmitt C, Dibra A, et al. One year outcomes with abciximab vs. placebo during percutaneous coronary intervention after pretreatment with clopidogrel. Eur Heart J. 2005;26(14):1379-1384.

47. Kastrati A, Mehilli J, Neumann FJ, et al. Abciximab in patients with acute coronary syndromes undergoing percutaneous coronary intervention after clopidogrel pretreatment: the ISAR-REACT 2 randomized trial. JAMA. 2006;295(13):1531-1538.

48. Bhatt DL, Topol EJ. Current role of platelet glycoprotein Iib/IIIa inhibitors in acute coronary syndromes. JAMA. 2000;284(12):1549-1558.

49. Coller BS. Platelet GPIIb/IIIa antagonists: the first anti-integrin receptor therapeutics. J Clin Invest. 1997;100(11 Suppl):S57-S60.

50. Ammar T, Scudder LE, Coller BS. In vitro effects of the platelet glycoprotein Iib/IIIa receptor antagonist c7E3 Fab on the activated clotting time. Circulation. 1997;95(3):614-617.

51. Michelson AD. Antiplatelet therapies for the treatment of cardiovascular disease. Nat Rev Drug Discov. 2010;9(2):154-169.

52. Scarborough RM, Rose JW, Hsu MA, et al. Barbourin. A GPIIbIIIa-specific integrin antagonist from the venom of Sistrurus m. barbouri. J Biol Chem. 1991;266(15):9359-9362.

53. Randomised placebo-controlled trial of effect of eptifibatide on complications of percutaneous coronary intervention: IMPACT-II. Integrilin to Minimise Platelet Aggregation and Coronary Thrombosis-II. Lancet. 1997;349(9063):1422-1428.

54. Gilchrist IC, O'Shea JC, Kosoglou T, et al. Pharmacodynamics and pharmacokinetics of higher-dose, double-bolus eptifibatide in percutaneous coronary intervention. Circulation. 2001;104(4):406-411.

55. Novel dosing regimen of eptifibatide in planned coronary stent implantation (ESPRIT): a randomised, placebo-controlled trial. Lancet. 2000;356(9247):2037-2044.

56. Kleiman NS, Lincoff AM, Flaker GC, et al. Early percutaneous coronary intervention, platelet inhibition with eptifibatide, and clinical outcomes in patients with acute coronary syndromes. PURSUIT Investigators. Circulation. 2000;101(7):751-757.

57. Stone GW, Bertrand ME, Moses JW, et al. Routine upstream initiation vs deferred selective use of glycoprotein Iib/IIIa inhibitors in acute coronary syndromes: the ACUITY Timing trial. JAMA. 2007;297(6):591-602.

58. Giugliano RP, White JA, Bode C, et al. Early versus delayed, provisional eptifibatide in acute coronary syndromes. $N$ Engl $J$ Med. 2009;360(21):2176-2190

59. Cannon CP, Weintraub WS, Demopoulos LA, et al. Comparison of early invasive and conservative strategies in patients with unstable coronary syndromes treated with the glycoprotein Iib/IIIa inhibitor tirofiban. $N$ Engl J Med. 2001;344(25):1879-1887. 
60. Topol EJ, Moliterno DJ, Herrmann HC, et al. Comparison of two platelet glycoprotein Iib/IIIa inhibitors, tirofiban and abciximab, for the prevention of ischemic events with percutaneous coronary revascularization. N Engl J Med. 2001;344(25):1888-1894.

61. Jing BB, Li YX, Zhang H, et al. Antithrombotic activity of Z4 A5, a new platelet glycoprotein Iib/IIIa receptor antagonist evaluated in a rabbit arteriovenous shunt thrombosis model. Thromb Res. 2011;128(5):463-469.

62. Hoylaerts MF. Platelet-vessel wall interactions in thrombosis and restenosis role of von Willebrand factor. Verh K Acad Geneeskd Belg. 1997;59(3):161-183

63. Pareti FI, Fujimura Y, Dent JA, Holland LZ, Zimmerman TS, Ruggeri ZM. Isolation and characterization of a collagen binding domain in human von Willebrand factor. J Biol Chem. 1986;261(32):15310-15315.

64. Nichols WL, Hultin MB, James AH, et al. von Willebrand disease (VWD): evidence-based diagnosis and management guidelines, the National Heart, Lung, and Blood Institute (NHLBI) Expert Panel report (USA). Haemophilia. 2008;14(2):171-232.

65. Gibbins JM, Okuma M, Farndale R, Barnes M, Watson SP. Glycoprotein VI is the collagen receptor in platelets which underlies tyrosine phosphorylation of the Fc receptor gamma-chain. FEBS Lett. 1997;413(2):255-259.

66. Kageyama S, Yamamoto H, Nakazawa H, et al. Pharmacokinetics and pharmacodynamics of AJW200, a humanized monoclonal antibody to von Willebrand factor, in monkeys. Arterioscler Thromb Vasc Biol. 2002;22(1):187-192.

67. Gilbert JC, DeFeo-Fraulini T, Hutabarat RM, et al. First-in-human evaluation of anti von Willebrand factor therapeutic aptamer ARC1779 in healthy volunteers. Circulation. 2007;116(23):2678-2686.

68. Knobl P, Jilma B, Gilbert JC, Hutabarat RM, Wagner PG, JilmaStohlawetz P. Anti-von Willebrand factor aptamer ARC1779 for refractory thrombotic thrombocytopenic purpura. Transfusion. 2009;49(10):2181-2185.

69. Siller-Matula JM, Merhi Y, Tanguay JF, et al. ARC15105 is a potent antagonist of von Willebrand factor mediated platelet activation and adhesion. Arterioscler Thromb Vasc Biol. 2012;32(4):902-909.

70. Vanhoorelbeke K, Depraetere H, Romijn RA, Huizinga EG, De Maeyer M, Deckmyn H. A consensus tetrapeptide selected by phage display adopts the conformation of a dominant discontinuous epitope of a monoclonal anti-VWF antibody that inhibits the von Willebrand factor-collagen interaction. J Biol Chem. 2003;278(39): 37815-37821.

71. De Meyer SF, Staelens S, Badenhorst PN, et al. Coronary artery in-stent stenosis persists despite inhibition of the von Willebrand factor-collagen interaction in baboons. Thromb Haemost. 2007;98(6):1343-1349.

72. Massberg S, Konrad I, Bultmann A, et al. Soluble glycoprotein VI dimer inhibits platelet adhesion and aggregation to the injured vessel wall in vivo. FASEB J. 2004;18(2):397-399.

73. Schulz C, Penz S, Hoffmann C, et al. Platelet GPVI binds to collagenous structures in the core region of human atheromatous plaque and is critical for atheroprogression in vivo. Basic Res Cardiol. 2008;103(4):356-367.

74. Ungerer M, Rosport K, Bultmann A, et al. Novel antiplatelet drug revacept (Dimeric Glycoprotein VI-Fc) specifically and efficiently inhibited collagen-induced platelet aggregation without affecting general hemostasis in humans. Circulation. 2011;123(17):1891-1899.

75. Zafar MU, Ibanez B, Choi BG, et al. A new oral antiplatelet agent with potent antithrombotic properties: comparison of DZ-697b with clopidogrel a randomised phase I study. Thromb Haemost. 2010;103(1):205-212.

76. Huizinga EG, Tsuji S, Romijn RA, et al. Structures of glycoprotein Ibalpha and its complex with von Willebrand factor A1 domain. Science. 2002;297(5584):1176-1179.

77. Uff S, Clemetson JM, Harrison T, Clemetson KJ, Emsley J. Crystal structure of the platelet glycoprotein Ib(alpha) N-terminal domain reveals an unmasking mechanism for receptor activation. J Biol Chem. 2002;277(38):35657-35663.
78. Wu D, Vanhoorelbeke $\mathrm{K}$, Cauwenberghs $\mathrm{N}$, et al. Inhibition of the von Willebrand (VWF)-collagen interaction by an antihuman VWF monoclonal antibody results in abolition of in vivo arterial platelet thrombus formation in baboons. Blood. 2002;99(10):3623-3628.

79. Hennan JK, Swillo RE, Morgan GA, et al. Pharmacologic inhibition of platelet Vwf-GPIb alpha interaction prevents coronary artery thrombosis. Thromb Haemost. 2006;95(3):469-475.

80. Yang J, Ji S, Dong N, Zhao Y, Ruan C. Engineering and characterization of a chimeric anti-platelet glycoprotein Ibalpha monoclonal antibody and preparation of its Fab fragment. Hybridoma (Larchmt). 2010;29(2):125-132.

81. Bender AT, Beavo JA. Cyclic nucleotide phosphodiesterases: molecular regulation to clinical use. Pharmacol Rev. 2006;58(3):488-520.

82. Schror K. The pharmacology of cilostazol. Diabetes Obes Metab. 2002;4 Suppl 2:S14-S19.

83. Liu Y, Fong M, Cone J, Wang S, Yoshitake M, Kambayashi J. Inhibition of adenosine uptake and augmentation of ischemia-induced increase of interstitial adenosine by cilostazol, an agent to treat intermittent claudication. J Cardiovasc Pharmacol. 2000;36(3):351-360.

84. Uehara S, Hirayama A. Effects of cilostazol on platelet function Arzneimittel-Forschung. 1989;39(12):1531-1534.

85. Suri A, Forbes WP, Bramer SL. Effects of CYP3 A inhibition on the metabolism of cilostazol. Clin Pharmacokinet. 1999;37 Suppl 2: 61-68

86. Suh JW, Lee SP, Park KW, et al. Multicenter randomized trial evaluating the efficacy of cilostazol on ischemic vascular complications after drug-eluting stent implantation for coronary heart disease: results of the CILON-T (influence of CILostazol-based triple antiplatelet therapy $\mathrm{ON}$ ischemic complication after drug-eluting stenT implantation) trial. J Am Coll Cardiol. 2011;57(3):280-289.

87. Angiolillo DJ, Capranzano $\mathrm{P}$, Goto S, et al. A randomized study assessing the impact of cilostazol on platelet function profiles in patients with diabetes mellitus and coronary artery disease on dual antiplatelet therapy: results of the OPTIMUS-2 study. Eur Heart J. 2008;29(18):2202-2211.

88. Aktas B, Utz A, Hoenig-Liedl P, Walter U, Geiger J. Dipyridamole enhances $\mathrm{NO} / \mathrm{Cgmp}$-mediated vasodilator-stimulated phosphoprotein phosphorylation and signaling in human platelets: in vitro and in vivo/ ex vivo studies. Stroke. 2003;34(3):764-769.

89. Gamboa A, Abraham R, Diedrich A, et al. Role of adenosine and nitric oxide on the mechanisms of action of dipyridamole. Stroke. 2005;36(10):2170-2175.

90. Diener HC, Cunha L, Forbes C, Sivenius J, Smets P, Lowenthal A. European Stroke Prevention Study. 2. Dipyridamole and acetylsalicylic acid in the secondary prevention of stroke. J Neurol Sci. 1996;143(1-2):1-13.

91. Halkes PH, van Gijn J, Kappelle LJ, Koudstaal PJ, Algra A. Aspirin plus dipyridamole versus aspirin alone after cerebral ischaemia of arterial origin (ESPRIT): randomised controlled trial. Lancet. 2006;367(9523):1665-1673.

92. Giannarelli C, Zafar MU, Badimon JJ. Prostanoid and TP-receptors in atherothrombosis: is there a role for their antagonism? Thromb Haemost. 2010;104(5):949-954.

93. Hong TT, Huang J, Driscoll E, Lucchesi BR. Preclinical evaluation of S18886 in an experimental model of coronary arterial thrombosis. J Cardiovasc Pharmacol. 2006;48(5):239-248.

94. Bousser MG, Amarenco P, Chamorro A, et al. Terutroban versus aspirin in patients with cerebral ischaemic events (PERFORM): a randomised, double-blind, parallel-group trial. Lancet. 2011;377(9782):2013-2022.

95. Tanaka T, Fukuta Y, Higashino R, et al. Antiplatelet effect of Z-335, a new orally active and long-lasting thromboxane receptor antagonist. Eur J Pharmacol. 1998;357(1):53-60.

96. Matsuno H, Uematsu T, Niwa M, et al. Pharmacokinetic and pharmacodynamic properties of a new thromboxane receptor antagonist (Z-335) after single and multiple oral administrations to healthy volunteers. J Clin Pharmacol. 2002;42(7):782-790. 
97. Cyrus T, Yao Y, Ding T, Dogne JM, Pratico D. A novel thromboxane receptor antagonist and synthase inhibitor, BM-573, reduces development and progression of atherosclerosis in LDL receptor deficient mice. Eur J Pharmacol. 2007;561(1-3):105-111.

98. Tchana-Sato V, Dogne JM, Lambermont B, et al. Effects of BM-573, a thromboxane A2 modulator on systemic hemodynamics perturbations induced by U-46619 in the pig. Prostaglandins Other Lipid Mediat. 2005;78(1-4):82-95.

99. Chackalamannil S, Wang Y, Greenlee WJ, et al. Discovery of a novel, orally active himbacine-based thrombin receptor antagonist (SCH 530348) with potent antiplatelet activity. J Med Chem. 2008;51(11):3061-3064.

100. Chintala M, Strony J, Yang B, Kurowski S, Li Q. SCH 602539, a protease-activated receptor-1 antagonist, inhibits thrombosis alone and in combination with cangrelor in a Folts model of arterial thrombosis in cynomolgus monkeys. Arterioscler Thromb Vasc Biol. 2010;30(11):2143-2149.

101. Becker RC, Moliterno DJ, Jennings LK, et al. Safety and tolerability of SCH 530348 in patients undergoing non-urgent percutaneous coronary intervention: a randomised, double-blind, placebo-controlled phase II study. Lancet. 2009;373(9667):919-928.

102. Morrow DA, Scirica BM, Fox KA, et al. Evaluation of a novel antiplatelet agent for secondary prevention in patients with a history of atherosclerotic disease: design and rationale for the ThrombinReceptor Antagonist in Secondary Prevention of Atherothrombotic Ischemic Events (TRA 2 degrees P)-TIMI 50 trial. Am Heart J. 2009;158(3):335-341.e3.
103. Kogushi M, Matsuoka T, Kawata T, et al. The novel and orally active thrombin receptor antagonist E5555 (Atopaxar) inhibits arterial thrombosis without affecting bleeding time in guinea pigs. Eur J Pharmacol. 2011;657(1-3):131-137.

104. Serebruany VL, Kogushi M, Dastros-Pitei D, Flather M, Bhatt DL. The in-vitro effects of E5555, a protease-activated receptor (PAR)-1 antagonist, on platelet biomarkers in healthy volunteers and patients with coronary artery disease. Thromb Haemost. 2009;102(1):111-119.

105. Goto S, Ogawa H, Takeuchi M, Flather MD, Bhatt DL, Investigators JL. Double-blind, placebo-controlled Phase II studies of the proteaseactivated receptor 1 antagonist E5555 (atopaxar) in Japanese patients with acute coronary syndrome or high-risk coronary artery disease. Eur Heart J. 2010;31(21):2601-2613.

106. Chintala M, Shimizu K, Ogawa M, Yamaguchi H, Doi M, Jensen P. Basic and translational research on proteinase-activated receptors: antagonism of the proteinase-activated receptor 1 for thrombin, a novel approach to antiplatelet therapy for atherothrombotic disease. J Pharmacol Sci. 2008;108(4):433-438.
Journal of Blood Medicine

\section{Publish your work in this journal}

The Journal of Blood Medicine is an international, peer-reviewed, open access, online journal publishing laboratory, experimental and clinical aspects of all topics pertaining to blood based medicine including but not limited to: Transfusion Medicine; Blood collection, Donor issues, Transmittable diseases, and Blood banking logistics; Immunohematology; Artificial and alternative

\section{Dovepress}

blood based therapeutics; Hematology; Biotechnology/nanotechnology of blood related medicine; Legal aspects of blood medicine; Historical perspectives. The manuscript management system is completely online and includes a very quick and fair peer-review system. Visit http://www.dovepress.com/ testimonials.php to read real quotes from published authors. 